\title{
Domestic Consequences of US Counter-Terrorism Efforts: Making it Harder to Prevent Homegrown Terrorism
}

\author{
Alice LoCicero*
}

Boston Medical Center, Boston, MA, USA

\begin{abstract}
This paper begins by recounting concerns, raised by various American psychologists regarding psychological consequences of US counterterrorism policies following the attacks of September 11, 2001 (9/11.) Predictions made by a task force created by the American Psychological Association to consider the likely social effects of US counterterrorism policies have proved accurate. These include not only fear, but widespread crippling panic resulting from vague warnings and lack of suggested actions; discrimination, resulting from increased emphasis on in-group vs. out-group identities; hate crimes against those perceived as members of out-groups, and lack of tolerance for antiwar perspectives. Recent, increasingly radical, changes in policy, such as widespread surveillance of US citizens' actions and communications by various US agencies, have led to more dire consequences, with many now concerned that the US is at risk of becoming a police state. The combined and interactive effects of earlier and more recent changes in US counterterrorism policies have caused serious, sometimes terrible, consequences. This paper explains how these consequences have become part of a vicious circle: frightened, passive, and unable to collaborate in rational attempts to manage the threat of terrorism, citizens have not begun to consider how to prevent future instances of homegrown terrorism.
\end{abstract}

Keywords: Terrorism, Counter-terrorism, United States, Social Psychology, Unintended Consequences.

A well- regarded body of social psychology research can be used to predict how communities will react to shared experiences of war, trauma, disaster, fear, conflict, and the perception of others as insiders or as outsiders [1]. This body of research was initially inspired by the wish to understand how such horrendous events as the Holocaust and World War II could have occurred. The work, which is of great value to society, continued to develop when later wars and conflicts were studied [2]. Following the 9/11 attacks, the American Psychological Association (APA) formed a task force to use this body of research and engage in new research to study and comment on the government's responses to the terrorist attacks. Members of the task force on the "Psychological Effects of Efforts to Prevent Terrorism" observed early effects and predicted likely longer term, unintended, adverse outcomes of counterterrorism policies. The goal was for APA to be able to advise the government on ways to prevent or at least reduce potential adverse outcomes of counterterrorism policies, while continuing to try to prevent further terrorist attacks. In an unanticipated turn of events that foreshadowed APA's uncritical support for US counterterrorism actions, the report of the Task Force was detoured, delayed, and then voted down by the APA Board of Directors and by the APA Council of Representatives, and subsequently shelved [3].

*Address correspondence to this author at the Center for Multicultural Training in Psychology, Boston Medical Center, Fuller Building, $9^{\text {th }}$ Floor, 85 E. Newton St. Boston, MA 02118 USA; Tel: 617-686-6606

Fax: 617-812-582; E-mail: alice.locicero@bmc.org
After the APA withdrew support for their work, task force members published the reports in the 2006 book, Collateral Damage [4]. They wrote about specific likely ill effects of policies such as the use of color-coded designations to signal levels of terrorism threat. In the foreword to the book, psychologist Phil Zimbardo argues that these threat level changes generate fear of an undefined danger without providing suggestions for possible actions. This omission inadvertently enhances the intended effects of terrorist actions: psychological terror, crippling anxiety, and difficulty in making decisions on a rational basis. In short, Americans were even more likely to respond to terrorism with panic than with reasonable actions. This panic was a result of being told to be afraid of a vague threat by an unknowable enemy and not being told how to cope or how to reduce the threat [5]. Such unproductive fear of terrorism has been shown to have measurable consequences, such as psychological distress and constriction of activities [6].

Other effects of US counterterrorism policies accurately predicted by the APA task force have also come to pass. These effects include increases in hate crimes against marginalized groups; intolerance for antiwar perspectives; acceptance of measures favoring security over freedom; and enhanced recruitment by terrorist groups, who use negative reactions to US policies as a recruiting tool. The collective adverse impacts of the ongoing counter terrorism policies have had the predictable and predicted deleterious impacts on US society. 


\section{HATE CRIMES AND HATEFUL BEHAVIOR TOWARD FRIGHTENED CHILDREN}

Various groups track hate crimes toward Arab Americans and Muslims, and those who look to others like they may be Muslim. These groups report sharp increases in such crimes shortly after 9/11. The American Civil Liberties Union (ACLU) noted that government leaders are effective in reducing hate crimes when they forcefully speak against discrimination [7]. Still Islamophobia has become a common and familiar phenomenon. The existence of harmful stereotypes and the consequent discrimination and violations of civil rights of Muslims and Arabs in America are largely tolerated without an outcry from non-Muslims [8]. Even worse in its effects than random hate crimes against those who appear to be Muslim or Arab, is the increase in frequency of racial and ethnic "profiling" by American police, border security agents, and airport screeners. Such profiling has frequently been observed. Adding insult to the injurious effect of profiling is the impunity enjoyed by police and security, and the secrecy with which the rules and procedures governing security are held [9].

Besides anti-Muslim sentiment, the US has seen a rise in prejudice toward other marginalized groups. Recently, a nearly unthinkable spectacle highlighted just how far down the road to hatred towards all "outsider" and marginalized groups Americans have come. In a series of horrendous events covered incessantly by mainstream press, ordinary American adults are seen derogating and threatening children who have come from Central American countries to seek asylum in the United States. Many of these children came to the United States for safety because they believed they would be killed by gangs if they remained in their home countries. Ignorance on the part of Americans abounded. Some Americans asserted that the children's parents had sent them here in an opportunistic spirit. They asserted that the children should simply be put on planes and sent home [10]. In some parts of the country, neither officials nor law enforcement professionals were seen to decry these words or actions. In addition, the government itself has detained mothers and their children who have also come in desperation, placing them in terrible conditions and expediting deportation with little or no legal counsel. This treatment is particularly inhuman and degrading in that reports indicate that sick children are not being given adequate care, a clear violation of international treaties ratified by the United States. The rationale for rushed deportation is reported to be to discourage other mothers and their children from seeking asylum in the US. Government officials have often set extraordinarily high bail for those who argue successfully that they should be allowed to leave the detention centers [11].

\section{SECURITY OVER FREEDOM}

Thirteen years after the 9/11 attacks, security concerns have led to a monstrously huge security and intelligence apparatus in the US. Citizens, as well as noncitizens, are still being profiled, detained without explanation, inconvenienced, and indeed, hassled without cause. More than a decade after $9 / 11$, even permanent residents of the US worry about traveling outside the country. They fear being viewed with suspicion or having difficulty returning to the country. Law enforcement has been infiltrating Muslim communities, aggressively seeking informants, or creating fake terrorist plots and attempting to draw young Muslims in. Federal agents interview thousands of young Arab American and Muslim men "with no individualized suspicion of criminal activity" [12].

\section{SECURITY OVER PRIVACY}

In the years since 9/11, Americans have gradually learned of the diminution of privacy. At first, the major concern was that companies would capture all sorts of data based on consumer habits and internet use. Soon Americans learned that data captured by companies was being made available to the government. Ultimately, Americans learned that the government was actively intervening in seeing to it that consumer electronics provided surveillance data, even in the absence of any suspicion, much less evidence, that the user of those electronics had any ill will toward the United States. Indeed, with the revelations by former NSA contractor Edward Snowden and others, Americans and others learned that the NSA and other western security agencies have been collecting mountains of data. This data is not only collected on suspected enemies of the United States, but even on friendly allies, and on innocent Americans themselves [13]. The reaction of Americans has been, it seems, muted. Perhaps this is a result of the gradual erosion of privacy rights over years, or because of the sense that threats abound, without knowledge of the nature of the threat or what to do about it. Americans now have become used to living with fear of an unknown and unknowable enemy, generated by government and media. Thus, it is likely that Americans' belief in their own ability to make good decisions about what sort of data is needed or might be useful to combat that unknowable enemy is likely to be impaired. In such states of fear, people are apt to expect the authorities to know best about how to counter any threat.

\section{VALUING SECURITY ABOVE INTERNATIONAL COMMITMENTS}

The effects of counterterrorism policies, especially taken together, appear to have deeply scarred the American reputation and psyche. Prisoners of war--who were, in a transparent and ultimately unsuccessful attempt to skirt international treaties - called "enemy combatants," were detained, often with little or no evidence, and with no charges placed against them. Many "enemy combatants" were detained for years, tortured, and then, when they went on hunger strikes, were force-fed in inhuman ways, further violating international conventions [14].

The highly respected former Four Star American General and later CIA Director David Petraus had stated clearly in 2009 that he believed it likely that the military had violated the Geneva Conventions in the post 9/11 era. (Soon thereafter, revelations about his personal life caused a scandal that led to his resignation in 2012) [15]. Such violations of the Geneva Conventions continue to take place at so called Black Box facilities, such as the prison at Guantanamo Bay, where a Navy nurse, earlier this year, refused to force feed detainees in the inhuman way that has 
become standard there. He is now at risk of having his Navy career terminated resulting from his refusal to obey orders that he was convinced were unlawful [16]. This risk is despite the ratified international principle that following orders is not an acceptable defense for engaging in unlawful behavior, such as cruel and inhuman treatment [17].

It is worrisome to imagine the long-term impact on Americans of seeing authorities endorse a long list of violations of international treaties, engage in torture, and punish those who refuse to violate international treaties to which the US is a signatory. It remains to be seen whether awareness of such violations, without direct experience of terror, will have a brutalizing effect similar to that seen in communities that have experienced trauma and violence firsthand [18]. Considering the media's focus and sometimes idealization of government-sanctioned violence, such as war and brutal treatment of detainees, one cannot avoid being concerned about the potential emergence of new values and new norms. Such new norms are likely to be driven less by civility and egalitarianism and more by fear and power dynamics.

Beyond the effects on ordinary Americans, it is worrisome to imagine the way that these actions in violation of international treaties are perceived outside the US, or by those who may be immigrants to the US, but who have dual allegiances, one of them being to a group that the US has targeted. It seems highly likely that these actions, taken in violation of international treaties, will be used by groups seeking to recruit youth to engage in anti-western terrorist actions. Such recruitment will increase the likelihood of homegrown terrorism.

\section{POPULARITY OF PRO-WAR VIEWS, UNPOPULARITY OF ANTI-WAR VIEWS}

AND

US counterterrorism policies have created hostility toward those who express antiwar perspectives. The unpopularity and intolerance for antiwar perspectives were expected. Beyond intolerance for antiwar perspectives, extreme pro-war imagery and enthusiasm has abounded. Military and security forces have become popular topics in Hollywood and on television. Government sanctioned violence, such as war, is idealized, rather than thoughtfully debated. Local police are now in possession of military style weaponry, vehicles, and gear. As witnessed in the summer of 2014, in Ferguson, Missouri, the use of this gear has a predictable effect: it makes the police more aggressive [19]. This could easily have been predicted (and thus avoided) by using principles of psychological science. When pro-war sentiment waned, as a result of the protracted and unsuccessful wars in Iraq and Afghanistan, it was easily regenerated by hysteria created by government and media portrayals of a group calling itself the Islamic State (although it is neither Islamic nor a state.) Although the government could not define or specify any threat to the US by this group, it insisted, and media portrayed, that such a threat was certain.

The group calling itself the Islamic State (more accurately called an un-Islamic, non-State) tried to get the US to provide ransom for the release of an American held hostage, James Foley. The government refused, and also informed members of Foley's family, who considered trying to raise money and provide the ransom themselves, that it would be unlawful to do so [20]. When the group then, in a dramatic and well-publicized procedure, beheaded Foley and other American hostages, the actions of the media and government, rather than putting Americans' fears into perspective in order to prevent panic, increased the panic.

At MacDill Air Force Base on September 19, 2014, President Obama made comments, later summarized and distributed by the White House, about the so-called Islamic State, (referred to in the comments as "ISIL"). The puzzling claim that ISIL is definitely threatening America, even though no specific plots have been detected, and no action is recommended, is reminiscent of the problems with colorcoded threat levels referred to above. Vague suggestions of something to be afraid of with no suggested action to take, other than, perhaps, to support the bombings targeted at the group calling itself Islamic State, has, as would have been predicted, caused panic and hysteria among Americans. Here is part of a summary of those comments, as distributed by the White House.

1. ISIL is threatening America and our allies. Our intelligence community has not yet detected specific plots from ISIL against our homeland, but they have repeatedly threatened our core interests, including our personnel, our embassies, our consulates, and our facilities in Iraq, Syria, and in the broader Middle East. "If left unchecked, they could pose a growing threat to the United States," he said [21].

The continued generation of fear of this group had the effect anticipated by the APA task force: polls showed that over $50 \%$ of Americans favored bombing the group, even though knowledge of the group was limited and the bombing was seen as likely to have complicated consequences. In fact, among Republican party members, 68\% approved the bombing and $57 \%$ said they would approve sending ground troops to battle this group [22].

\section{CREATION OF TERRORISM HYSTERIA}

Over the years since $9 / 11$, fear of terrorism has morphed into what might be called hysteria. By hysteria, I refer to two elements: Excessive fear, and inability to assess the fear rationally. While the so-called Islamic State deliberately engenders fear, Americans' fear of the so-called Islamic State group is disproportionate to the actual risk. That is not to suggest that there is no danger from terrorism. Consider, however, that there is much less palpable panic, much less news reporting, and much less money invested in the dangers of smoking, alcohol use, automobile accidents, firearms, poverty, or obesity, all of which kill far more Americans than terrorism. Terrorism hysteria is just what terrorists want to create: Confusion, panic, paralysis, inability to create an effective response.

Reflecting on the origins and maintenance of terrorism hysteria in the US over the years since September 11, 2001, I find multiple likely sources, as described above. (a) Historical use of color-coded "threat levels." (b) Illconceived and poorly executed actions by the FBI where the intent was to capture potential terrorists, but the outcome 
was to generate an inaccurate perception that the threat of homegrown terrorism was much greater than it actually is [23]. (c) Extreme and unwarranted intelligence gathering by government agencies. (d) Using the term "terrorist" to justify targeting people for detention with concomitant denial of rights mandated by international treaty. (e) Targeting of Arab and Muslim Americans and those resembling Arab or Muslim Americans with the suggestion that they may be a threat, including lengthy unexplained detainments at the border, improbable "random" selection for additional screening at airports, unjustified and repeated interview requests, and infiltration of Muslim-American communities [24].

Factors listed and explained in this paper do not account for all terrorism hysteria. Additional factors that contribute to terrorism hysteria have been noted. They are worthy of consideration, but they are beyond the scope of this paper. (f) Enrichment of private corporations that manufacture weapons and other military equipment by fears that lead to support for military intervention [25]. (g) Demonization and threatened prosecution of people and organizations of good will, such as Humanitarian Law Project, who, the Supreme Court decided, were aiding terrorists by teaching them nonviolent methods to get their grievances addressed [26]. (h) Disproportionate focus on Muslim militant groups when identifying groups as posing terrorist threats [27]. (i) Supplying of arms and money to governments widely perceived as violators of human rights, while publicly referring to them as allies in the fight against terrorism. (j) Use of the term "terrorist" to describe foes in preparing the country to endorse military action against them. (k) Public refusal to talk to terrorists, in spite of the evidence that that has worked in conflicts that previously had seemed intractable, such as in Northern Ireland and South Africa. (This stance appears to many outside and some inside the US to reflect arrogance, stubbornness, and perhaps weak motivation to resolve legitimate grievances.)

\section{COMPETENCE AT DISASTER RESPONSE}

Following the Boston Marathon bombings in 2013, several things occurred that Bostonians could celebrate: A combination of medically trained people and Good Samaritans immediately and effectively attended injured victims. Triage and transport were accomplished efficiently. Medical centers provided excellent care.

A simple donation structure (the One Fund) was established, so that those wishing to give money had no doubt about how to do so. Victim service organizations met the immediate needs of those affected. Thousands of Boston area businesses, health care providers, and others provided free services, from medical care to weddings. Boston area residents provided meaningful, unending expressions of warmth, support, and assistance.

Besides all that, officials also established a simple, catchy slogan, "Boston Strong," that conveyed the ability of the public to manage and rebound from the disruption and disturbance caused by this terrible event. As a public health measure, the use of this term has been quite successful. This is not to imply that there was not much suffering, including-but not limited to-long term and ongoing physical, psychological, and economic trauma, experienced by many in Boston. Rather the slogan implied that the city would rebound and now it implies that the city has rebounded. The first anniversary of the bombing was marked with a combination of gravity, awareness of loss, and some celebration of the progress made. It reflected the determination not to be bowed. The 2014 Boston marathon was celebrated and had no significant adverse events. In a commitment to continue its support, the city now has two centers specifically dedicated to providing ongoing services to those affected adversely by the bombings.

Lessons learned about the response to the marathon have been incorporated into many cities' disaster plans. These include lessons learned from the perspective of law enforcement, security, and first response. Lessons learned about long term consequences and needs to be met for those affected are also being recorded in order to be incorporated into planning.

\section{WHAT ABOUT EARLY PREVENTION?}

While much work has been done, thousands have given selflessly, the city has largely rebounded, and lessons have been learned and incorporated, one area has largely remained untouched. That is the area of early prevention of future socalled homegrown terrorism. Early prevention, in this context, means preventing youth from becoming amenable to recruitment to domestic or international terrorist groups.

Ordinary Americans - such as parents, teachers, coaches, neighbors, aunts, uncles, mentors, clergy, peers-have the most important role in preventing kids from being recruited, and thus the most important role in preventing so-called homegrown terrorism. This is the conclusion drawn by a variety of researchers in several countries in the EU, and in the US. A document issued by the White House suggests that the US government should support local communities in their efforts to assist kids who appear to be on a path that may lead to recruitment. However, little has been done nationally, and virtually nothing has yet been done in the Boston area [28].

It appears that thirteen years of counterterrorism efforts have largely left American citizens passive, fearful, confused, and irrational-not in their reactions to actual terrorism, but in their reactions to the threat of future terrorism. Well-meaning adults have little sense of how to prevent children in their own communities from being radicalized, recruited, and convinced that the best way to help a cause that they are convinced is a good one is to act in ways that are disruptive, violent, and guaranteed to end their own possibility of having a productive life.

Researcher Anne Speckhardt spent a great deal of time talking to terrorists. She has written a compelling account of her work. In it she says

"What I learned above all else is that no one is born a terrorist. Something has got to put them on the terrorist trajectory, and if we are clever in our approaches to dealing with terrorists, we can also take them back off of it [sic]." [29]. 
If we can take people off the "terrorist trajectory," as many in the EU believe, developing ways to do so would be prudent. However, in the US, the tendency is to think of people who become terrorists as somehow having had the seeds of evil in them since birth. Conversations in the city where the accused marathon bombers grew up suggest that people believe the city did everything it could for them, that the community did everything right, and that there is nothing that could have been done differently or that should be done differently to prevent a repeat of this horrible turn of events. This contrasts starkly with the conclusions of researchers around the world.

If communities take Speckhardt and other researchers seriously, they must ask questions that have become, in the thirteen years since September 11, counterintuitive. Questions like the following: What can citizens do to see that kids are on a path towards a satisfying and productive life, or to help them return to such a path? What is our responsibility toward youth who might be at risk of recruitment? How can we inoculate youth against recruitment? How do recruiters get the attention of youth in the United States in the first place? What needs are the recruiters promising to meet? How can those needs be met in ways that do not cause violence and end the possibility of productive lives for the youth at risk?

The beginning of all efforts toward primary prevention is knowledge. There are multiple case studies of youth who become terrorists. Some are depictions of individuals and others are composite sketches. I have used principles from various social sciences, applied to the accused Boston Marathon bombers and others in Why Good Kids Become Terrorists: Deconstructing the Accused Boston Marathon Bombers and Others Like Them [30]. Research for that book inspired this essay, as I found, in talking to many researchers and many citizens, that there is a serious disconnect between researchers' understanding of what it will take to prevent homegrown terrorism, and citizens' (in)ability to imagine themselves having a role.

Research suggests that people in communities consider informal and ongoing discussions among themselves, that they not wait for the government or law enforcement to establish avenues for prevention. This might include reading research on young terrorists and even viewing and reading recruitment materials to understand how they might appeal to youth in their own communities. Concerned citizens would be prudent to inform local officials and law enforcement that they are engaging in these discussions. The risk to citizens educating themselves about terrorism is that the very people who want to discourage and prevent terrorism will become the targets of enhanced surveillance and suspicion. The NSA and other security agencies will surely have information that these citizens are being exposed to materials about why terrorism might be appealing, and the possibility that this will lead to misunderstanding is, at present, a consequential risk.

Adults who are concerned about youth recruitment will have several challenges. They will have to to overcome thirteen years of unintended consequences of government induced hysteria, passivity, anxiety, and panic. They will have to learn to take a calm, patient, rational, approach to educating themselves about kids, terrorism, and the draw of violence. They will have to be prepared to learn about the existence of legitimate grievances; about the government's actions that unintentionally aid recruitment, and so on. They will also have to be prepared to endure some degree of suspicion and concern by government agents or others, who may not, initially, readily understand or accept their intentions. Ultimately, they will have to listen to the youth in their communities, hear what is on the minds of the youth, and assist them in finding meaningful, nonviolent approaches to addressing real-life legitimate grievances. In this process, adults and youth alike will engage in critical thinking and engaged citizenship, thus creating the model for sustainable engagement in nonviolent political and social action.

Communities that wish to prevent recruitment to terrorism will have one additional challenge: resisting the government's program called Countering Violent Extremism (CVE). This program, presented as a way to prevent homegrown terrorism, is being planned but has not yet officially launched. It is likely to have the opposite of its intended effect, as, in its present form, it is likely to isolate and demonize youth who are seen as engaging in "suspicious" activity. Rather than strengthening communities in their efforts to support youth and assist them, it is likely to turn communities against young people who are in need of community support [31].

\section{CONFLICT OF INTEREST}

The authors confirms that this article content has no conflict of interest.

\section{ACKNOWLEDGEMENTS}

Declared none.

\section{REFERENCES}

[1] Asch SE. Opinions and social pressure. Sci Am 1955; 193: 31-5.

[2] Bandura A. Moral disengagement in the perpetration of inhumanities. Person Soc Psychol Rev 1999; 3: 193-209.

[3] Welch B. The American Psychological Association and torture: the day the tide turned. huffington post blog. Posted 08-29-2009. Reference available from: http://www.huffingtonpost.com/bryantwelch/the-american-psychologica_b_242020.html. Retrieved on October 19, 2015.

[4] Kimmel P, Stout CE, Eds. Collateral damage: psychological consequences of America's War on terror. Westport, CT: Praeger 2006.

[5] Zimbardo P. In: Kimmel PE, Stout CE, Eds. Collateral damage: Psychological consequences of America's war on terror. Westport, CT: Praeger 2006.

[6] Sinclair SJ, LoCicero A. Fearing future terrorism: development, validation, and psychometric testing of the terrorism catastrophizing scale (TCS). Traumatology 2007; 13: 75-90.

[7] Murphy L, MacLeod-Ball MW, Senate Judiciary Subcommittee on the Constitution, Civil Rights and Human Rights. Protecting the civil rights of Muslim Americans. March 29, 2011. Available from https://www.aclu.org/files/assets/March_2011_Hearing_on_Musli m_Civil_Rights_Statement.pdf [Retrieved on October 20,2014].

[8] Arab-American AntiDiscrimination Committee. Legal Advocacy and Policy Review: The 2010 Legal Advocacy Report Available from:

http://issuu.com/adcnational/docs/2010adclegalreport?e=2064637/5 378719. [Retrieved on October 20, 2014].

[9] Abdurrahman,S. My detainment story or: How I learned to stop feeling safe in my own country and hate border agents. On the 
Media, WNYC Radio, September 20, 2013. Available from: http://www.onthemedia.org/story/my-detainment-story-or-how-ilearned-stop-feeling-safe-my-own-country-and-hate-border-patrol/ [Retrieved on October 20, 2014].

[10] Abdullah, H. Not in my backyard: Communities protest surge of immigrant kids. CNN. July 16, 2014. Available from: http://www.cnn.com/2014/07/15/politics/immigration-not-in-mybackyard/ [Retrieved on October 20, 2014]

[11] American Immigration Lawyers Association. AILA: Expansion of Family Detention Means the United States Will Jail More Victims of Violence. September 23, 2014. Available from: http://www.aila.org/content/default.aspx?docid=50181 [Retrieved on October 20, 2014].

[12] American Civil Liberties Union. Raza v. City of New York - Legal Challenge to NYPD Muslim Surveillance Program. June, 2013. Available from: https://www.aclu.org/national-security/raza-v-citynew-york-legal-challenge-nypd-muslim-surveillance-program. [Retrieved on October 20, 2104].

[13] The NSA Files. The Guardian. 2014. Available from: http://www.theguardian.com/us-news/the-nsa-files [Retrieved on October 20, 2014].

[14] Zapotosky, M. Guantanamo Bay detainee force feeding case continues. Washington Post. October 7, 2014. Available from: http://www.washingtonpost.com/world/national-

security/guantanamo-bay-detainee-force-feeding-case-

continues/2014/10/07/04544bb2-4e52-11e4-aa5e-

7153e466a02d_story.html. [Retrieved on October 20, 2014].

[15] Soltz, J. Petraeus Says U.S. Violated Geneva Conventions - What Will Cheney and Rush Say? Huffington Post Blog. August 29, 2009. Available from: http://www.huffingtonpost.com/jonsoltz/petraeus-says-us-violated_b_209215.html [Retrieved on October 20, 2014].

[16] Rosenberg, C. Navy nurse refuses to force feed Guantanamo captive. Miami Herald. July 14, 2014. Available from: http://www.miamiherald.com/news/nation-

world/world/americas/article1975643.html [Retrieved October 20, 2014].

[17] United Nations. Principles of International Law Recognized in the Charter of the Nürnberg Tribunal and in the Judgment of the Tribunal. 1950. Available from: http://legal.un.org/ilc/texts/instruments/english/draft\%20articles/7_ 1_1950.pdf [Retrieved on October 31, 2014].

[18] Somasundaram D. Short- and long-term effects on the victims of terror in Sri Lanka. J Aggress Maltreat Trauma 2004; 9: 215-28.

[19] Berkowitz L, LePage A. Weapons as aggression-eliciting stimuli J. Person Soc Psychol 1967; 7: 202-7.

[20] Callmachi, R. For James Foley's family, U.S. policy offered no hope. New York Times. September 15, 2014. Available from: http://www.nytimes.com/2014/09/16/us/for-hostages-family-uspolicy-offered-no-hope.html [Retrieved October 20, 2014].
[21] White House Office of the Press Secretary. Remarks by the President at MacDill Air Force Base. September 17, 2014. Available from: http://www.whitehouse.gov/the-pressoffice/2014/09/17/remarks-president-macdill-air-force-base. [Retrieved on September 18, 2014].

[22] Pew Research Center for the People and the Press. Support for U.S. Campaign against ISIS; Doubts about Its Effectiveness, Objectives. October 22, 2014. Available from: http://www.peoplepress.org/2014/10/22/support-for-u-s-campaign-against-isisdoubts-about-its-effectiveness-objectives/. [Retrieved November 2 , 2014].

[23] Human Rights Watch. Illusion of justice: Human rights abuses in US terrorism prosecutions. Report by Human Rights Watch and Columbia Law School Human Rights Institute. Human Rights Watch. 2014. Available from: http://www.hrw.org/reports/ 2014/07/21/illusion-justice-0 [Retrieved on October 18, 2014].

[24] Arab-American AntiDiscrimination Committee. Legal Advocacy and Policy Review: The 2010 Legal Advocacy Report Available from: http://issuu.com/adcnational/docs/2010adclegalreport?e= 2064637/5378719 [Retrieved on October 20, 2014].

[25] Weigley S. Ten companies profiting the most from war. USA Today, March 10, 2013. Available from: http://www.usatoday.com/ story/money/business/2013/03/10/10-companies-profiting-most-

from-war/1970997/. [Retrieved October 20, 2014].

[26] Cole D. The first amendment's borders: The place of Holder v. Humanitarian Law Project in first amendment doctrine. Georgetown Public Law and Legal Theory Research Paper No. 12 047, 2012: 147-177. Available on the internet at http://scholarship.law.georgetwon.edu/facpub/853

[27] Beck CJ, Miner E. Who gets designated a terrorist and why? Soc Forces 2013: 837-72.

[28] Norwegian Ministry of Justice and the Police. Security: a shared responsibility. action plan to prevent radicalization and extremism. Available http://www.regjeringen.no/upload/JD/Vedlegg/Handlingsplaner/Ra dikalisering_engelsk.pdf [Retrieved October 17, 2014].

[29] Speckhard A. Talking to terrorists: Understanding the psychosocial motivations of militant Jihadi terrorists, mass hostage takers, suicide bombers \& martyrs to combat terrorism in prison and community rehabilitation. (Kindle Locations 15908-15910). Villa Park, IL: Advances Press 2012.

[30] LoCicero A. Why good kids turn into deadly terrorists: Deconstructing the accused Boston Marathon bombers and others like them. Santa Barbara, CA: Praeger 2014

[31] US Department of Homeland Security. Counering Violent Extremism. October 15, 2014. Available from: http://www.dhs.gov/topic/countering-violent-extremism [Retrieved November 18, 2014].

(C) Alice LoCicero; Licensee Bentham Open.

This is an open access article licensed under the terms of the Creative Commons Attribution Non-Commercial License (http://creativecommons.org/licenses/by-nc/3.0/) which permits unrestricted, non-commercial use, distribution and reproduction in any medium, provided the work is properly cited. 